FACTA UNIVERSITATIS

Series: Philosophy, Sociology, Psychology and History Vol. 20, N $^{\circ}$ 1, 2021, pp. 1 - 11

https://doi.org/10.22190/FUPSPH2101001J

Original Scientific Paper

\title{
GRATITUDE AND LONELINESS AS PREDICTORS OF SUBJECTIVE WELL-BEING
}

\author{
UDC 159.942
}

\section{Ana Jovančević, Nebojša Milićević}

\author{
University of Niš, Faculty of Philosophy, Department of Psychology, Serbia
}

\begin{abstract}
The main aim of this research is to analyze the role of loneliness found in previous studies as well as to examine the role of gratitude as one of the main factors contributing to subjective well-being. The sample is a convenience sample and consists of 219 respondents (78.99\% women). The instruments used in this research were: the Social and Emotional Loneliness Scale for Adults (SELSA; di Tomasso \& Spinner, 1993), the Life satisfaction scale (SWLS; Diener, Emmons, Larsen, \& Griffin, 1985), PANAS (Watson, Clark, \& Tellegan, 1988) and The Gratitude Questionnaire (McCullough et al., 2002). The data were analyzed using a hierarchical linear regression where the criterion variables were components of subjective well-being, the predictor in the first step gratitude, and predictors in the second step three types of loneliness. The results of this research show that the only statistically significant predictor of positive affects is gratitude (model 1: $\beta=.281, p<.01$; model 2: $\beta=.243 . p<.01)$. Gratitude and loneliness explain $30.1 \%$ of the variance of positive affect. When it comes to negative affect, the first model explains $12.6 \%$ of the variance, while the second model explains $21.9 \%$ of the total variance. Only the second model is statistically significant $(p<.05)$. The only statistically significant predictor is loneliness in the family $(\beta=.143 . p=.049)$. Finally, when it comes to life satisfaction, the first model explains $23.5 \%$ of the variance while the second model explains $38.6 \%$ of the total variance. When loneliness is added in the second model, an additional $15.1 \%$ of the statistically significant explained variance appears $(p<.01)$. The best predictor in this regression analysis is social loneliness $(\beta=-.297, p<.01)$. Based on these results we can conclude that both gratitude and loneliness are important variables for subjective well-being - but that some are more important for some and some for other aspects of subjective well-being.
\end{abstract}

Key words: Gratitude, subjective well=being, social loneliness, loneliness in the family, loneliness in love.

Received June 10, 2020 / Accepted July 31, 2020

Corresponding author: Ana Jovančević

University of Niš, Faculty of Philosophy, Ćirila i Metodija 2, 18000 Niš, Serbia

E-mail: ana.jovancevic@ filfak.ni.ac.rs

(ㅇ 2021 by University of Niš, Serbia | Creative Commons License: CC BY-NC-ND 


\section{INTRODUCTION}

Subjective well-being is a concept that researchers, as one of the key concepts of mental health today, are showing considerable interest in. By "subjective well-being" we think of what people most often call happiness or contentment (Diener, Oishi, \& Lucas 2003). The very phrase "subjective well-being" was introduced because concepts such as happiness or pleasure are saturated with a large number of different meanings. Since it is new, at the same time neutral, this term gives the possibility for a more precise definition, which was not possible with the notions of happiness and satisfaction. Edward Diner says that the term subjective well-being is actually a synonym for happiness, only more scientific and less confusing (Diener \& Scollon 2003). Accordingly, in this paper we will use both terms, treating them as synonyms. According to Diner's definition, subjective well-being is an "affective and cognitive evaluation of life." (Diener 2000) and consists of two components: 1. A cognitive (long-term) component which refers to a person's global assessment of his life satisfaction. Life satisfaction can be defined as a one-dimensional construct that refers to the extent to which the respondent is satisfied with life in general, that is, how close his life is to the ideal according to him; 2. An affective (short-term) component consisting of: positive affect and low-level negative affect. Positive affect implies frequent experience of pleasant emotions, while a low level of negative affect refers to rare experiences of unpleasant emotions.

Ruut Veenhoven, a sociologist and one of the prominent researchers in the field of subjective well-being, gives a similar definition of the term "subjective well-being". He also considers happiness to be synonymous with subjective well-being and defines it as "the overall assessment of life that comes from two sources of information: a cognitive comparison with the standard of good living and affective information about how one feels most of the time." (Veenhoven 2008, 45). Subjective well-being occupies a prominent place in modern models of mental health (Keyes 2006).

The definition of subjective well-being that we will be guided by in this research is the first mentioned definition, the one given by Edward Diner and his associates (Diener, Oishi, \& Lucas 2003). The reason for choosing this definition is that it is actually the first more complete definition of happiness, which takes into account the affective component of happiness (simply how happy a person is), as well as its cognitive component (how satisfied a person is with different aspects of his life). This definition, therefore, takes into account both components of happiness, while earlier authors chose either one or the other component in their research.

Gratitude is considered to be one of the main constructs in Positive Psychology and a construct which has been neglected until the development of the area of psychology now mentioned (Emmons \& McCullough, 2003). When it comes to what gratitude is, this construct can be interpreted both as a state and as a trait. Gratitude as a state refers to positive emotions when individuals experiences an act of kindness from another person (McCullough, Emmons, \& Tsang 2002), while gratitude as a trait refers to individuals' disposition to experience this state (Chan 2010).

McCullough and associates (2002) write about the facets of a grateful disposition. These authors presume the existence of the following gratitude facets: Intensity - a dispositionally grateful person will feel gratitude with higher intensity; Frequency - a person prone to gratitude will feel it more often from those not so prone to it; Span - this facet refers to the aspects of life for which a person is grateful for; conversely, a person 
with a higher disposition towards gratitude will be grateful for a higher range of life aspects (e.g. family, job, life itself...) from individuals' not to prone to gratitude; and, the final gratitude facet is Density - referring to the number of persons' one feel grateful to.

Gratitude was shown to be a very important variable for subjective well-being (Chan 2010). For example, Chan (2010) showed that gratitude can predict social support, adaptive coping mechanisms and life satisfaction (as an aspect of subjective well-being). On the other hand, gratitude decreases an avoidant coping style and negative emotions. Further, research shows that gratitude can predict a substantial amount of well-being variance beyond the contributions of personality traits (Lin 2014; Wood, Joseph, \& Maltby 2009) making it a uniquely important variable for subjective well-being. Gratitude provides us with a more optimistic point of view on both our general experiences (McCullough, Emmons, \& Tsang, 2004) and our relationships (Gordon, Arnette, \& Smith 2011). Furthermore, those with higher disposition towards gratitude were also found to be happier (McCullough et al. 2004; Wood, Froh, \& Geraghty 2010). The important role of gratitude in subjective well-being was also found in a sample of Hong Kong teachers (Chan 2013).

It should also be stated that certain moderators between gratitude and well-being were found. So, for example, it was found that ambivalence towards emotion expression inhibited the effect of gratitude on happiness (Chen, Chen, \& Tsai, 2012). Also, one more important theoretical finding for our study is the one which suggests that those individuals who are high in ambivalence towards expressing their emotions also perceive less social support (Chen et al. 2012).

Based on the aforementioned, the following variable in our research is loneliness. Loneliness refers to an individuals' perception of their relationships, characterized by those relationships being perceived as not the ones that individual expected (Nicolaisen \& Thorsen 2014).

Further, when it comes to loneliness, it has been shown that gratitude, subjective happiness and life satisfaction are statistically significant predictors of loneliness (Caputo 2015). Gratitude was proven to be a protective factor against loneliness (Ni, Yang, Zhang, \& Dong 2015). Loneliness was also proven to be a significant mediator between gratitude and physical health (O'Connell, O'Shea, \& Gallagher 2016).

Another construct in this research is that of social relations, or more precisely, loneliness in different types of social relations (in a partnership, friendship, family relationship). To understand the importance of social relations for people and their mental health, it is necessary to return to the views of one of the most famous psychologists, more precisely, William McDougall and the gregarian motif. Man's need to associate with other people was first described by the aforementioned author and he called it a gregarian motif (Ognjenović 2005). McDougall considered this motif innate and attributed a relaxing effect to it (Ognjenović 2005). If McDougall's assumption about the aspiration to associate and, consequently, the relaxing effect of the same is correct, the question arises whether it is reasonable to assume that associating with others, through the relaxing effect it has on people, will lead to greater subjective well-being. Previous studies aimed at shedding light on the relationship between the quality of social relations and subjective well-being confirmed this assumption. Very happy people have been shown to have better romantic and other relationships than those who are less happy (Diener \& Seligman 2002). They give better grades to their friendly, romantic and family relationships than people who consider themselves very unhappy. Very happy people also spend less time alone and more in company (Diener \& Seligman 2002). In one study, 
people were asked at random periods during the day how happy they were. The results have shown that people are the happiest when they are with their friends, more than when they are with family members or when they are alone (Larson, Mannell, \& Zuzanek 1986). Also, it has been shown that social relations do not lead to greater happiness only when we receive social support, but also when we provide it (Brown et al. 2003).

The problem with these studies is reflected in the fact that different authors have operationalized social and emotional loneliness in different ways. In a study by Diner and Seligman (Diener \& Seligman 2002) the respondents' assessment of the quality of their social and emotional relationships was measured, while loneliness was measured by the question of how much time during the day the respondents spend alone and how much in society. In a study by Larson et al. (Larson, Mannell, \& Zuzanek 1986) respondents filled out questionnaires at random periods during the day in which, among other things, they gave answers to questions about how happy they were at that moment, as well as what exactly they were doing at that moment. In this study, we decided to introduce a variable related to social and emotional loneliness. According to theory, loneliness in the domain of friendship is a construct of social loneliness, while loneliness in the domain of family and love relationships is emotional loneliness (Ćubela-Adorić \& Nekić 2006). The main aim of this research is to check the role of loneliness found in previous studies mentioned above, as well as other studies conducted in our country (Jovančević 2019) as well as to examine the role of gratitude as one of the main factors contributing to subjective wellbeing - as it was shown in this introduction.

\section{METHOD}

\subsection{Sample and procedure}

The sample is a convenience sample and consists of 219 respondents from Serbia (78.99\% women). The age of the respondents ranges from 18 to 61 years, and the average age is $25.28(\mathrm{SD}=8.14)$.

The data were collected online, via google forms.

\subsection{Instruments}

2.2.1. Social and Emotional Loneliness Scale for Adults (SELSA; diTomasso \& Spinner 1993). The scale was adapted for a Serbian linguistic environment (Ćubela-Adorić \& Nekić 2006). The scale of social and emotional loneliness consists of three measurement subjects: Social loneliness (13 items), Loneliness in the family (11 items) and Loneliness in love (12 items). It is a seven-point Likert-type scale, where $1=\mathrm{I}$ completely disagree, and $7=\mathrm{I}$ completely agree.

The scale has adequate internal consistency reliability on this sample (Social loneliness: $\alpha=.92$; Loneliness in the family: $\alpha=.92$; Loneliness in love: $\alpha=.94$ ). In a previous study (Ćubela-Adorić and Nekić 2006), the reliability was as follows: Social loneliness $\alpha=.88$; Loneliness in the family $\alpha=.85$ and Loneliness in love $\alpha=.91$.

2.2.2. Life satisfaction scale (SWLS; Diener, Emmons, Larsen \& Griffin 1985). The life satisfaction scale is used to measure the cognitive component of subjective well-being. It consists of five items that measure the individual's evaluation of life satisfaction in general. It is a seven-point Likert-type scale, in which $1=\mathrm{I}$ completely disagree, and $7=\mathrm{I}$ completely 
agree. The average score of the answers to the five questions represents the overall life satisfaction score.

The scale has a satisfactory internal consistency reliability on this sample $(\alpha=.91)$. In one of the previous studies in our linguistic environment (Vasić, Šarčević \& Trogrlić 2011) the reliability of the scale was $\alpha=.88$.

2.2.3. PANAS (Watson, Clark, \& Tellegan, 1988). The PANAS scale refers to the measurement of the affective component of subjective well-being. It consists of twenty items. Ten items measure the expression of positive emotions (e.g.: enthusiasm, pride), while the other ten items measure the expression of negative emotions (e.g.: shame, sadness). The instruction that the respondents had in front of them required them to answer the questions taking into account their feelings in the past week, so that the positive and negative affect in this research were operationalized as a condition, and not as a personality disposition. It is a five-point Likert-type scale, where $1=$ Very little or not at all, and $5=$ Completely. The expression of positive affect was obtained by summing up the responses to items related to positive affect. The same goes for calculating the overall score for negative affect.

The scale has a satisfactory internal consistency reliability on the sample of this research (Positive affect: $\alpha=.85$; Negative affect: $\alpha=.89$ ). The reliability obtained in our sample coincides with the reliability reported by the authors of the scale (Watson et al., 1988), which is between $\alpha=.86$ and $\alpha=.90$ for positive affect and between $\alpha=.84$ and $\alpha=.87$ for negative affect.

2.2.4. The Gratitude Questionnaire (McCullough et al. 2002) is a 6-item measure designed to assess individual differences in the proneness to experience gratitude in daily life. The reliability of this questionnaire in our study was satisfactory $(\alpha=.605)$. In the original study (McCullough et al., 2002) the reliability of the Gratitude questionnaire was high $(\alpha=.85)$.

\subsection{Data analysis}

In this research correlation and hierarchical linear regression was used as a method of data analysis. In the regression analysis criterion variables were components of subjective well-being (positive affect, negative affect and life satisfaction) while predictor variables were Gratitude and three types of Loneliness (social, family and loneliness in love). Gratitude was a predictor in the first step because in this research it is defined as a trait, while loneliness is a state. Taking that into account, gratitude was a predictor in the first step of the regression analysis.

\section{RESULTS AND DISCUSSION}

From Table 1 it can be seen that not all the intercorrelations are in accordance with the multicollinearity criterion. When it comes to the predictors, we can see all the intercorrelations are lower than .7, which is in accordance with the multicollinearity rule. On the other hand, when it comes to the relation between the predictors and criterion variables, not all the correlations are statistically significant and higher than .3 (this is true for positive affect and negative affect as criterion variables, but not for life satisfaction). These results suggest the possible effect of multicollinearity on the final results of this study - taking that into account, the statistical power will be calculated through Gpower software. 
Table 1 Intercorrelation between study variables

\begin{tabular}{lrcrc}
\hline Correlations & $\begin{array}{l}\text { Loneliness } \\
\text { in love }\end{array}$ & $\begin{array}{l}\text { Loneliness } \\
\text { in Family }\end{array}$ & $\begin{array}{l}\text { Social } \\
\text { loneliness }\end{array}$ & Gratitude \\
\hline Loneliness in love & & & & \\
Loneliness in Family & $.205^{*}$ & & & \\
Social loneliness & $.279^{*}$ & $.357^{* *}$ & & \\
Gratitude & $-.250^{*}$ & $-.277^{* *}$ & $-.426^{* *}$ & \\
Positive affect & -.044 & -.109 & $-.206^{* *}$ & $.285^{* *}$ \\
Negative affect & .065 & $.189^{*}$ & $.163^{*}$ & -.125 \\
Life satisfaction & $-.340^{* *}$ & $-.343^{* *}$ & $-.507^{* *}$ & $.489^{* *}$ \\
\hline \multicolumn{4}{c}{ Note: $^{* *}$ - statistically significant at .01 } & \\
& $*$ - statistically significant at .05 &
\end{tabular}

From Table 2 it can be seen that the only statistically significant predictor is gratitude (model 1: $\beta=.281, p<.01$; model 2: $\beta=.243$. $p<.01$ ). The first model explains $28.1 \%$ of variance of the positive affect, while the second model explains $30.1 \%$ of the total variance of positive affect. These results are in accordance with the previous studies (Chan 2010; Lin 2014; Wood et al. 2009; Gordon et al. 2011; Wood et al. 2010; Chan 2013) which all suggest that gratitude is one of the key variables for subjective well-being. On the other hand, it can be seen that Loneliness is not a very important variable for positive affect. These results are not in accordance with the previous studies (Jovančević 2019). For example, Jovančević (2019) showed that we can predict positive affect through loneliness and that social loneliness was a statistically significant predictor of Positive affect. Combining these results, we can assume that the variance the social loneliness predicted in that study was due to the gratitude trait, for when we insert gratitude into the equation - Social loneliness is not an important predictor anymore.

Table 2 Regression analysis: Predicting Positive affect by Gratitude and Loneliness

\begin{tabular}{|c|c|c|c|c|c|c|c|c|c|}
\hline Model & Predictors & $\mathrm{R}$ & $\overline{\mathrm{R}^{2}}$ & $\mathrm{~F}$ & $\begin{array}{c}\mathrm{R}^{2} \\
\text { change }\end{array}$ & $\begin{array}{c}\mathrm{F} \\
\text { change }\end{array}$ & $\begin{array}{c}\mathrm{p} \\
\text { change }\end{array}$ & $\beta$ & $\mathrm{p}$ \\
\hline Model 1 & & .281 & .079 & 18.413 & & & & & .000 \\
\hline & Gratitude & & & & & & & .281 & \\
\hline Model 2 & & .301 & .091 & 5.257 & .011 & .882 & .451 & & .000 \\
\hline & Gratitude & & & & & & & .243 & .001 \\
\hline & Loneliness in love & & & & & & & .051 & .466 \\
\hline & Loneliness in the family & & & & & & & -.012 & .868 \\
\hline & Social loneliness & & & & & & & -.112 & .143 \\
\hline
\end{tabular}

In order to check the hypothesis stated above, we tried a different sequence of predictors - Loneliness first, followed by Gratitude.

The first model, the model with only Loneliness, was statistically significant $(\mathrm{p}<.05)$ and Social loneliness was indeed a statistically significant predictor of positive affect $(\beta=198 ; p<.05)$ but its significance was lost in the second model when gratitude was added $(\beta=-.112 ; p>.05)$. So, on the basis of all these results we can assume that Loneliness is indeed a significant predictor of positive affect, and that gratitude is a mediator of that relation. The mediation is, presumably, a total mediation because loneliness stops to be a significant predictor when gratitude is added in the equation. 
Taking all these results into account we can assume that those who are lonely are to a lesser extent prone to positive affect and those who are grateful are prone to positive affect to a higher extent. Further, previous studies show that gratitude was proven to be a protective factor against loneliness (Ni, Yang, Zhang, \& Dong 2015). Based on those results, we can assume that loneliness is an important variable until gratitude is taken into account, because gratitude, as a protective factor against loneliness, changes an individual's perspective on how lonely he or she is - rendering gratitude a more important variable for positive affect proneness.

Statistical power for the first model was .98 and for the second model .95 .

From Table 3 it can be seen that the first model explains $12.6 \%$ of the variance of Negative affect, while the second model explains $21.9 \%$ of the total variance of negative affect. But only the second model is statistically significant $(\mathrm{p}<.05)$. The only statistically significant predictor is loneliness in the family $(\beta=.143 . p=.049)$.

Table 3 Regression analysis: Predicting Negative affect by Gratitude and Loneliness

\begin{tabular}{|c|c|c|c|c|c|c|c|c|c|}
\hline Model & Predictors & $\mathrm{R}$ & $\mathrm{R}^{2}$ & $\mathrm{~F}$ & $\begin{array}{c}\mathrm{R}^{2} \\
\text { change }\end{array}$ & $\begin{array}{c}\mathrm{F} \\
\text { change }\end{array}$ & $\begin{array}{c}\mathrm{p} \\
\text { change }\end{array}$ & $\beta$ & $\mathrm{p}$ \\
\hline Model 1 & & .126 & .016 & 3.458 & & & & & .064 \\
\hline & Gratitude & & & & & & & -.126 & .064 \\
\hline Model 2 & & .219 & .048 & 2.664 & .032 & 2.377 & .071 & & .034 \\
\hline & Gratitude & & & & & & & -.048 & .531 \\
\hline & Loneliness in love & & & & & & & -.002 & .979 \\
\hline & $\begin{array}{l}\text { Loneliness in the } \\
\text { family }\end{array}$ & & & & & & & .143 & .049 \\
\hline & Social loneliness & & & & & & & .092 & .240 \\
\hline
\end{tabular}

These results are in accordance with previous studies which suggest that poor relationship quality in the family circle is an important stressor which can take a toll on an individual's well-being (Thomas, Liu, \& Umberson, 2017). Furthermore, some studies have shown that family loneliness is a significant predictor of subjective well-being (Hombrados-Mendieta, García-Martín \& Gómez-Jacinto 2013; Jovančević 2019). In the study by Jovančević (2019) family loneliness was shown to be a significant predictor of negative affect. Taking all these results into account it can be concluded that family loneliness is indeed a significant predictor of negative affect. On the other hand, gratitude was not proven to be a significant predictor of negative affect although theory suggests that it is the most important variable for subjective well-being (Chan 2010; Lin 2014; Wood et al. 2009; Gordon et al. 2011; Wood et al. 2010; Chan 2013). We can assume that gratitude indeed is an important variable of subjective wellbeing in general, but when we look at the separate aspects of subjective well-being we can see more clearly what variables are the most important ones for what aspect of subjective well-being. From all this we can assume that when an individual feels lonely in family surroundings, that loneliness is what mostly impacts the negative emotions that individual experiences - trait gratitude becomes less important when family problems come to the light.

Since only the second model was statistically significant, and since the only significant predictor was loneliness in the family, we calculated the statistical power for that predictor. It was .99 . 
From Table 4 it can be seen that the first model explains $23.5 \%$ of the variance of life satisfaction, while the second model explains $38.6 \%$ of the total variance of life satisfaction. When loneliness is added in the second model, an additional $15.1 \%$ of the statistically significant explained variance appears $(\mathrm{p}<.01)$.

Table 4 Regression analysis: Predicting Life satisfaction by Gratitude and Loneliness

\begin{tabular}{llllllllll}
\hline Model & Predictors & $\mathrm{R}$ & $\mathrm{R}^{2}$ & $\mathrm{~F}$ & $\begin{array}{c}\mathrm{R}^{2} \\
\text { change }\end{array}$ & $\begin{array}{c}\mathrm{F} \\
\text { change }\end{array}$ & $\begin{array}{c}\mathrm{p} \\
\text { change }\end{array}$ & $\beta$ & $\mathrm{p}$ \\
\hline Model 1 & & & & & & & \\
\multicolumn{1}{l}{ Gratitude } & .485 & .235 & 65.648 & & & & .485 & .000 \\
Model 2 & & & & & & & .000 \\
& Gratitude & .621 & .386 & 33.117 & .151 & 17.279 & .000 & & .000 \\
& Loneliness in love & & & & & & & .283 & .000 \\
$\quad$ Loneliness in the family & & & & & & & -.160 & .006 \\
$\quad$ Social loneliness & & & & & & & -.126 & .032 \\
\end{tabular}

Gratitude $\beta$ value drops significantly in the second model (from $\beta=.485$ in the first model to $\beta=.283$ in the second model) suggesting that one of the types of loneliness is the mediator between gratitude and life satisfaction. Since social loneliness is the best predictor $(\beta=-.297, \mathrm{p}<.01)$ we can assume that this is the mediator in the relation between gratitude and life satisfaction.

The best predictor in this regression analysis is social loneliness $(\beta=-.297, p<.01)$. This is in accordance with some previous studies (Jovančević 2019).

These results are in accordance with studies suggesting that gratitude is an important variable for subjective well-being (Chan 2010; Lin 2014; Wood et al. 2009; Gordon et al. 2011; Wood et al. 2010; Chan 2013). They are also in accordance with previous studies suggesting that Loneliness is an important variable for subjective well-being (HombradosMendieta et al. 2013; Diener \& Seligman 2002; Larson et al. 1986). These results suggest that trait gratitude indeed leads to higher satisfaction with life, but that this relation is mediated by the social loneliness. We can now recall results which suggest that Loneliness was proven to be a significant mediator between gratitude and physical health (O'Connell et al. 2016). Furthermore, some studies suggest that very happy individuals spent less time alone and more time in the company of others (Diener \& Seligman 2002). Also, Larsen et al. (1986) suggest that people show a higher level of happiness when in the company of others. All these results taken together suggest, firstly, that those with a higher gratitude trait level are indeed more satisfied with their life. According to McCullought and associates (2002), and their classification of gratitude facets, those who feel gratitude with higher intensity and more often, those who are grateful for more things in their life and those who are grateful to more people in their life will also be more satisfied with their life. On the other hand, since loneliness was proven to be an important predictor of life satisfaction, these results can be understood if other studies are taken into account. For example, authors suggest that loneliness is a mediator between gratitude and physical health (O'Connell et al. 2016), and if this is true for physical health it could also be true for life satisfaction. Furthermore, on the basis of the results given here, it is possible that social loneliness is a mediator between gratitude and life satisfaction, and since the results from the previous studies suggest that people are happy the most when around other people (Diener \& Seligman 2002; Larson et al. 1986) this is also understandable. 
Although we do not expect multicollinearity for life satisfaction as a criterion variable, we have calculated statistical power for both models of this analysis. It was .99 for the first model and 1 for the second model.

Finally, we can now assume that those who have a higher level of gratitude are more satisfied with their life, but, if they feel lonely, the impact of gratitude is not that strong.

In the end, we can conclude that this study is in accordance with previous results regarding importance of gratitude for subjective well-being, and with those studies suggesting the importance of loneliness for subjective well-being. On the other hand, this study shows for which aspects of subjective well-being the gratitude is most important for. Namely, Gratitude was proven to be important for two out of three aspects of subjective well-being (Positive affect and Life satisfaction), but its importance for life satisfaction decreases when loneliness is added in the equation. Furthermore, it was shown that loneliness by itself is not a significant predictor of positive affect, but that Family loneliness is the only important predictor of negative affect, suggesting that Family dissatisfaction could be that key thing leading to negative emotions in individuals. Finally, all three types of loneliness were found to be significant predictors of life satisfaction.

\section{CONCLUSION}

The results of this paper show that both loneliness and gratitude are important variables for subjective well-being. The best and only statistically significant predictor of positive affect was gratitude. The best predictor of negative affect was family loneliness while the best predictor of life satisfaction was social loneliness. So, in conclusion, both loneliness and gratitude are important variables for subjective well-being. However, on the level of different aspects of subjective well-being, we can see that each of these variables has a different impact on different aspects of the subjective well being.

The theoretical contribution of this paper consists in deeper knowledge regarding subjective well-being - as one of the key constructs in mental health.

The practical contribution can be found in therapy or in workshops for enhancing subjective well-being and its components. Namely, when we know which aspects of personality lead to enhancement of which aspects of the subjective well-being, it becomes easier to work with individuals with low levels of subjective well-being with the goal of enhancing it.

The limitations of this research pertain to the demographic characteristics of the sample. Namely, for future research we suggest the inclusion of the same number of respondents with different education levels and also the control of the socio-economic background of the respondents. Since the sample in this research was a convenience sample, for future research we suggest some other sampling method, which would give us a more representative sample (for example a stratified sampling method). Furthermore, since the research was done online, all age groups and respondents of all economic backgrounds were surely not accounted for in this research, for which reason we suggest conducting this research in offline conditions in the future. We also suggest adding a mediation analysis in future research. 


\section{REFERENCES}

Caputo, Andrea. "The relationship between gratitude and loneliness: The potential benefits of gratitude for promoting social bonds". Europe's Journal of Psychology 11, 2 (2015): 323. doi: 10.5964/ejop.v11i2.826

Chan, David W. "Gratitude, gratitude intervention and subjective well-being among Chinese school teachers in Hong Kong". Educational Psychology 30, 2 (2010): 139-153. doi: 10.1080/01443410903493934

Chan, David W. "Subjective well-being of Hong Kong Chinese teachers: The contribution of gratitude, forgiveness, and the orientations to happiness". Teaching and Teacher Education 32 (2013): 22-30. doi: 10.1016/j.tate.2012.12.005

Chen, Lung Hung, Chen Mei-Yen, and Tsai Ying-Mei. "Does gratitude always work? Ambivalence over emotional expression inhibits the beneficial effect of gratitude on well-being". International Journal of Psychology 47, 5 (2012): 381-392. doi: 10.1080/00207594.2011.632009

Ćubela-Adorić, Vera i Marina Nekić. Zbirka psihologijskih skala i upitnika. Zadar: Sveučilište u Zadru, 2006.

Diener, Ed, Shigehiro Oishi, and Richard E. Lucas. "Personality, culture, and subjective well-being: Emotional and cognitive evaluations of life." Annual Review of Psychology 54, 1 (2003): 403-425. Retrieved from https://www.researchgate.net/profile/Shigehiro_Oishi/publication/11215086_Personality_Culture_and_Subjective _Well-Being_Emotional_and_Cognitive_Evaluations_of_Life/links/56635f1e08ae4931cd5edc1e/PersonalityCulture-and-Subjective-Well-Being-Emotional-and-Cognitive-Evaluations-of-Life.pdf

Diener, Ed, and Christie Scollon. "Subjective well-being is desirable, but not the summum bonum". In University of Minnesota Interdisciplinary workshop on well-being, 23-25. 2003.

Diener, Ed, and Martin E. P. Seligman. "Very happy people". Psychological Science 13, 1 (2002): 81-84. Retrieved from http://pcl.missouri.edu/jeff/sites/pcl.missouri.edu.jeff/files/Diener.pdf

Diener, Ed, Robert A. Emmons, Randy J. Larsen, and Sharon Griffin. "The satisfaction with life scale". Journal of Personality Assessment 49, 1 (1985): 71-75. doi: 10.1207/s15327752jpa4901_13

DiTommaso, Enrico, and Barry Spinner. "The development and initial validation of the Social and Emotional Loneliness Scale for Adults (SELSA)". Personality and Individual Differences 14, 1 (1993): 127-134.doi: $10.1016 / 0191-8869(93) 90182-3$

Gordon, Cameron L., Robyn A. M. Arnette, and Rachel E. Smith. "Have you thanked your spouse today?: Felt and expressed gratitude among married couples". Personality and Individual Differences 50, 3 (2011): 339-343. doi: 10.1016/j.paid.2010.10.012

Hombrados-Mendieta, Isabel, Miguel Angel García-Martín, and Luis Gómez-Jacinto. "The relationship between social support, loneliness, and subjective well-being in a Spanish sample from a multidimensional perspective". Social Indicators Research 114, 3 (2013): 1013-1034. doi: 10.1007/s11205-012-0187-5

Emmons, Robert A., and Michael E. McCullough. "Counting blessings versus burdens: an experimental investigation of gratitude and subjective well-being in daily life". Journal of Personality and Social Psychology 84, 2 (2003): 377. doi: 10.1037/0022-3514.84.2.377

Keyes, Corey L. M. "Subjective well-being in mental health and human development research worldwide: An introduction". Social Indicators Research 77, 1 (2006): 1-10. Retrieved from https://www.researchgate. net/profile/Corey_Keyes/publication/225113698_Subjective_Well-Being_in_Mental_Health_and_Human_ Development_Research_Worldwide_An_Introduction/links/0deec52b1f34c1b8e7000000/Subjective-Well-Beingin-Mental-Health-and-Human-Development-Research-Worldwide-An-Introduction.pdf

Larson, Reed, Roger Mannell, and Jiri Zuzanek. "Daily well-being of older adults with friends and family". Psychology and Aging 1, 2 (1986): 117. doi: 10.1037/0882-7974.1.2.117

Lin, Chih-Che. "A higher-order gratitude uniquely predicts subjective well-being: Incremental validity above the personality and a single gratitude". Social Indicators Research 119, 2 (2014): 909-924. Retrieved from https://www.researchgate.net/profile/Chih_Che_Lin2/publication/259635833_A_higherOrder_Gratitude_Uniquely_Predicts_Subjective_Well-

Being_Incremental_Validity_Above_the_Personality_and_a_Single_Gratitude/links/56532c6208ae1ef9297 5dec0/A-higher-Order-Gratitude-Uniquely-Predicts-Subjective-Well-Being-Incremental-Validity-Abovethe-Personality-and-a-Single-Gratitude.pdf

McCullough, Michael E., Robert A. Emmons, and Jo-Ann Tsang. "The grateful disposition: A conceptual and empirical topography". Journal of Personality and Social Psychology 82, 1 (2002): 112. doi: https://doi.org/10. 1037/0022-3514.82.1.112

McCullough, Michael E., Jo-Ann Tsang, and Robert A. Emmons. "Gratitude in intermediate affective terrain: links of grateful moods to individual differences and daily emotional experience". Journal of Personality and Social Psychology 86, 2 (2004): 295. doi: 10.1037/0022-3514.86.2.295

Nicolaisen, Magnhild, and Kirsten Thorsen. "Who are lonely? Loneliness in different age groups (18-81 years old), using two measures of loneliness". The International Journal of Aging and Human Development 78, 3 (2014): 229-257. doi: https://doi.org/10.2190/AG.78.3.b 
Ognjenović, Predrag. Naše namere i osećanja. Beograd: Gutenbergova galaksija, 2005.

O'Connell, Brenda H., Deirdre O'Shea, and Stephen Gallagher. "Mediating effects of loneliness on the gratitude-health link". Personality and Individual Differences 98 (2016): 179-183. doi: 10.1016/j.paid.2016.04.042

Thomas, Patricia A., Hui Liu, and Debra Umberson. "Family relationships and well-being". Innovation in Aging 1, 3 (2017): igx025. doi: 10.1093/geroni/igx025

Vasić, Aleksandar, Dušana Šarčević i Aleksandra Trogrlić. "Zadovoljstvo životom u Srbiji". Primenjena psihologija 4, 2 (2011): 151-177.doi: 10.19090/pp.2011.2.151-177

Veenhoven, Ruut. "Sociological theories of subjective well-being". The Science of Subjective Well-being 9 (2008): 44-61.

Watson, David, Lee Anna Clark, and Auke Tellegen. "Development and validation of brief measures of positive and negative affect: the PANAS scales". Journal of Personality and Social Psychology 54, 6 (1988): 1063. Google scholar.

Wood, Alex M., Stephen Joseph, and John Maltby. "Gratitude predicts psychological well-being above the Big Five facets". Personality and Individual differences 46, 4 (2009): 443-447. doi: 10.1016/j.paid.2008.11.012

Wood, Alex M., Jeffrey J. Froh, and Adam W. A. Geraghty. "Gratitude and well-being: A review and theoretical integration". Clinical Psychology Review 30, 7 (2010): 890-905. doi: 10.1016/j.cpr.2010.03.005.

\section{ZAHVALNOST I USAMLJENOST KAO PREDIKTORI SUBJEKTIVNOG BLAGOSTANJA}

Glavni cilj ovog istraživanja je provera uloge usamljenosti u doživljaju subjetktivnog blagostanja, koja je pronađena u prethodnim radovima, kao i provera toga koju ulogu zahvalnost kao crta ima $u$ doživljaju subjektivnog blagostanja - kao jednog od glavnih faktora ovog stanja pronađenog $u$ prethodnim radovima. Uzorak je prigodan i čini ga 219 ispitanika (78.99\% žena). Upitnici korišćeni u ovom istraživanju su sledeći: Skala socijalne i emocionalne usamljenosti za odrasle (SELSA; diTomasso \& Spinner 1993), Skala zadovoljstva životom (SWLS; Diener, Emmons, Larsen, \& Griffin 1985), PANAS (Watson, Clark, \& Tellegan 1988) i Upitnik Zahvalnosti (McCullough et al. 2002). Podaci su obrađivani hijerarhijskom regresionom analiziom gde su kriterijumi bile kompoenente subjektivnog blagostanja, prediktor u prvom koraku zahvalnost a prediktori u drugom koraku tri vrsted usamljenosti. Rezultati ovog istraživanja pokazuju da je jedini statistički značajan prediktor pozitivnog afekta zahvalnost (model 1: $\beta=.281, p<.01$; model 2: $\beta=.243 . p<.01)$. Zahvalnost i usamljenost zajedno objašnjavaju $30.1 \%$ varijanse pozitivnog afekta. Kada je u pitanju negativni afekat, prvi model objašnjava $12.6 \%$ varijanse dok drugi objašnjava 21.9\% varijanse negativnog afekta. Samo je drugi model statistički značajan $(p<.05)$. Jedini statistički značajan prediktor je usamljenost u porodoci $(\beta=.143 . p=.049)$. Konačno, kada je u pitanju zadovoljsto životom, prvi regresioni model objašnjava $23.5 \%$ varijanse dok drugi objašnjava $38.6 \%$ varijanse zadovoljstva životom. Kad se usamljenost ubaci u drugi korak regresije, statistički značajno se objašanjava dodatnih $15.1 \%(p<.01)$. Najbolji prediktor u ovoj regresionoj analizi je socijalna usamljenost $(\beta=-.297, p<.01)$. Na osnovu rezultata možemo da zaključimo da su i zahvalnost $i$ usamljenost bitne varijable za subjektivno blagostanje, ali $i$ to da kada je svaka od ovih varijabli $u$ različitoj meri bitna za različite aspekte subjektivnog blagostanja.

Ključne reči: zahvalnost, subjektivno blagostanje, socijalna usamljenost, usamljenost u porodici, usamljenost u ljubavi. 